\title{
Fine-Scale Spatial Genetic Structure in Perennial Grasses in Three Environments
}

\author{
Steven E. Smith, ${ }^{1}$ Tulio Arredondo, ${ }^{2}$ Martín Aguiar, ${ }^{3}$ Elisabeth Huber-Sannwald, ${ }^{2}$ Angel Alpuche, ${ }^{2}$ \\ Armando Aguado, ${ }^{4}$ Oscar A. Grageda, ${ }^{5}$ Kandres Halbrook, ${ }^{6}$ and Cecilia Bottini ${ }^{7}$ \\ Authors are ${ }^{1}$ Associate Professor and ${ }^{6}$ Graduate Research Assistant, School of Natural Resources, University of Arizona, Tucson, AZ 85721, USA; \\ ${ }^{2}$ Associate Professors, Instituto Potosino de Investigación Científica y Tecnológica, Division de Ciencias Ambientales, San Luis Potosi, SLP, Mexico; \\ ${ }^{3}$ Professor and ${ }^{7}$ Postdoctoral Associate, Instituto de Investigaciones Fisiológicas y Ecológicas Vinculadas a la Agricultura, Facultad de Agronomía, \\ Universidad de Buenos Aires/Consejo Nacional de Investigaciones Científicas y Tecnicas, Buenos Aires, Argentina; and ${ }^{4}$ Associate Professor and ${ }^{5}$ Research \\ Assistant, Instituto Nacional de Investigaciones Forestales, Agricolas y Pecuarias, Roque, Celaya, GTO, Mexico.
}

\begin{abstract}
Past research has shown that changes in grazing-resistance traits may be associated with genetic changes in plant populations. Little is known about spatial genetic relationships within plant populations (spatial genetic structure) and any grazing effects on these relationships. Here we present observations of the fine-scale spatial genetic structure in three grass species in semiarid environments (Arizona, Mexico, and Argentina). In each environment, populations of a dominant grass species were sampled from two sites with contrasting livestock grazing histories. Plant genotypes were described with the use of amplified fragment length polymorphism markers. In Arizona, populations of sideoats grama (Bouteloua curtipendula var. caespitosa Gould and Kapadia) differed in that one has never experienced livestock grazing, whereas cattle have grazed the other. In the other two environments, populations exposed to long-term heavy grazing were examined, along with those that experienced either moderate grazing (Mexico, blue grama [Bouteloua gracilis \{Willd. ex Kunt\} Lag. ex Griffiths]) or extended exclusion of livestock (Argentina [Poa ligularis Nees ex Steud.]). Based on independent analysis of each population, we observed no differences in average gene diversity between populations of each species. With the use of analysis of molecular variance we found slight but significant genetic differentiation between populations with different grazing histories in Arizona and Argentina. Significant genetic structure was present in all populations and indicated an inverse relationship between spatial and genetic distance. Interestingly, this relationship was most pronounced in the cattle-free sideoats grama population, suggesting larger genetic neighborhood areas in the absence of livestock. Less distinct differences in spatial genetic structure associated with grazing history were evident in the other two species. We hypothesize that livestock grazing may lead to increased homogeneity in genetic structure at the landscape scale. Effectively examining this hypothesis presents many experimental challenges.
\end{abstract}

\section{Resumen}

Investigaciones conducidas anteriormente ha mostrado que los cambios en las características a la resistencia al pastoreo quizá están asociados con los cambios genéticos en la población de las plantas. Muy poco se conoce acerca de la relación espacial genética entre la población de las plantas (la estructura genética espacial) y cualquier efecto del pastoreo en esta relación. Aquí presentamos observaciones a una escala fina de la estructura espacial genética en tres especies de gramíneas en un medio ambiente semiárido (Arizona, México, y Argentina). En cada medio ambiente, las poblaciones de las especies de gramíneas dominantes fueron muestreadas en dos sitios con historia de pastoreo contrastantes. Los genotipos de las plantas fueron descritos utilizando marcadores amplificados de fragmentos de polyformismo. En Arizona, las poblaciones de navajita (Bouteloua curtipendula var. caespitosa Gould and Kapadia) difieren en que nunca ha estado expuestas al pastoreo del ganado mientras que en las otras poblaciones han estado expuestas al pastoreo. En las otras dos zonas las poblaciones expuestas al pastoreo pesado por largo tiempo fueron examinadas junto con aquellas poblaciones que experimentaron pastoreo moderado (México, blue grama [Bouteloua gracilis \{Willd. ex Kunt\} Lag. ex Griffiths]) o una prolongada exclusión del pastoreo (Argentina [Poa ligularis Nees ex Steud.]). Basándose en un análisis independiente de cada población, observamos que no había diferencia en el promedio de la diversidad de genes entre la población de cada especie. Utilizando análisis de la varianza molecular se encontró una diferencia ligera pero una significante diferenciación genética entre las poblaciones con diferente historial de pastoreo en Arizona y Argentina. Significante estructura genética estuvo presente en todas las poblaciones y se encontró una relación inversa entre la distancia genética y la espacial. Interesantemente, esta relación estuvo más marcada en la población de navajita (sideoats grama) donde no existió el pastoreo, sugiriendo una mayor acercamiento genético en las aéreas donde el ganado estuvo ausente. Menor evidente fueron las diferencias en la estructura espacial genética relacionada con la historia del pastoreo en las otras dos especies. Tenemos las hipótesis que el pastoreo por el ganado puede incrementar la homogeneidad en la estructura genética a niveles de paisaje. El examen efectivo de esta hipótesis presenta varios retos experimentales.

Key Words: apomixis, genetic diversity, grasslands, grazing history

Research was funded in part by the InterAmerican Institute for Global Change Project SGP-019, the Arizona Agricultural Experiment Station and Arizona Crop Improvement Association, and the National Council of Scientific and Technical Research and the National Agency of Scientific and Technological Promotion (Argentina).

Correspondence: Steven E. Smith, School of Natural Resources, University of Arizona, 1311 E 4th St, Tucson, AZ 85721, USA. Email: azalfalf@ag.arizona.edu

Manuscript received 3 November 2008; manuscript accepted 19 April 2009. 


\section{INTRODUCTION}

Livestock grazing may represent a major factor shaping ecosystem composition, structure, and function at multiple scales (Milchunas and Lauenroth 1993; Milchunas et al. 1998; Asner et al. 2004; Sivakumar et al. 2005). At the population level, numerous changes have been documented in grazingresistance traits within plant populations in species that persist in the presence of livestock (e.g., Carman and Briske 1985; Poley and Detling 1990; Briske and Anderson 1992; Briske and Richards 1995; Smith 1998; Smith et al. 2000; Díaz et al. 2001; Arredondo et al. 2005). In some cases, these changes in functional traits have also been associated with changes in genetic variation (Smith 1998; Noy-Meir and Briske 2002). Such changes could influence evolutionary potential in the affected populations and have consequences on community and ecosystem properties (Folke et al. 2004; Crutsinger et al. 2006).

Genetic changes in plant populations associated with grazing animals have been investigated primarily with the use of neutral molecular markers. This permits a general description of any genetic consequences of grazing that may be independent of selection for grazing resistance (Matlaga and Karoly 2004). The typical experimental approach involves retrospective comparison of populations of a commonly grazed species in similar environments that differ in grazing history. Such experiments have emphasized population-wide assessment of genetic variation, including various measures of genetic diversity and interpopulation differentiation. In most cases, no differences in genetic diversity that can be related to livestock grazing history have been observed (Carman and Briske 1985; Tómas et al. 2000; Liston et al. 2003; Matlaga and Karoly 2004; Mengli et al. 2005). This conclusion is not universal, however (AguadoSantacruz et al. 2004; Fu et al. 2005).

To draw definitive conclusions about livestock effects on genetic parameters in plant populations 1) there must be similar environments (sites) with substantially different long-term grazing histories or imposed treatments, ideally including at least one with an extended period of livestock exclusion or reduced grazing intensity; and 2) populations of the plant species of interest must contain identifiable genetic variation. Because decades of grazing may be required for recognizable change in grazing-resistance traits to occur (Aarssen and Turkington 1987), this research often involves experimental sites where grazing treatments were imposed in the past independent of the current research objectives. Given that grazing treatments in these situations are nearly universally imposed in a nonrandom and unreplicated manner, this research often results in descriptive statistics, and great caution must be used in interpreting results (Scheiner and Gurevitch 2001).

Emphasis has been placed on genetic comparisons between populations with different grazing histories (e.g., Smith 1998). However, little importance has been placed on any effects of grazing livestock on genetic and spatial relationships within plant populations. These relationships may influence many microevolutionary processes, especially in cross-pollinated species where genetic relationships among neighboring plants are closely associated with offspring fitness (Heywood 1991).

We examined genetic diversity, population differentiation, and fine-scale spatial genetic structure (i.e., considering relationships among neighboring individuals within populations) in dominant perennial grass species in plant communities in three arid environments: southern Arizona, central Mexico, and west-central Argentina (Table 1). We hypothesized that significant genetic structure would exist in all populations. In each environment we examined amplified fragment length polymorphism (AFLP) markers in a grass species that previous research had shown to be genetically variable on paired sites with different grazing histories.

\section{METHODS}

\section{Experimental Populations}

Desert Grassland. We collected ramets (plants) from two populations of the facultatively apomictic (Harlan 1949; Gould 1951) caespitose grass, sideoats grama (Bouteloua curtipendula var. caespitosa Gould and Kapadia) in southern Arizona (Table 1). The populations are located on two neighboring sites in a semidesert grassland community (Brown 1994). One site (cattle free, lat $32^{\circ} 42.8^{\prime} \mathrm{N}$, long $110^{\circ} 29.1^{\prime} \mathrm{W}, 1655 \mathrm{~m}$ above sea level [a.s.l.]) is situated on a plateau inaccessible to cattle (Bos taurus L.) and other domesticated herbivores and represents a geological grazing refuge (Milchunas and Noy-Meir 2002). The other site (high grazing intensity) occurs on a similar somewhat smaller plateau $1500 \mathrm{~m}$ east of the cattle-free site that has been regularly grazed by cattle since the late 1800s (Hadley et al. 1991) at stocking rates of 11-13 ha $\cdot$ animal unit $(\mathrm{AU})^{-1}(\mathrm{G}$. Ruyle, personal communication, December 2008). (We use "low" or "high" to describe different grazing intensities relative to only the opposing population for that plant species at the experimental sites.) Both sites have Haplargid soils $(0.2-0.5 \mathrm{~m}$ deep) on 20-35\% slopes with numerous rock outcrops (D. Robinett, personal communication, April 2004). Sideoats grama is common in the area between the sites and the populations sampled may represent part of single larger ancestral population. Evidence for significant genetic differentiation for some functional traits has been demonstrated in sideoats grama populations from these sites (Smith 1998; Smith et al. 2000).

We excavated a total of 265 mature sideoats grama ramets (basal area $>15 \mathrm{~cm}$ ) in January 2003 along north-south transects on both sites. In the cattle-free population, 134 ramets were sampled (every $11 \mathrm{~m}$ over a $1463-\mathrm{m}$ transect). The high-grazing-intensity population existed on a smaller site. Accordingly, 131 ramets were sampled (every $6 \mathrm{~m}$ over a 780$\mathrm{m}$ transect). The distance between adjacent sampled ramets was reduced in this population to increase the chance of identifying relatively small patches (diameter: $<20 \mathrm{~m}$ ) of genetically related ramets should they occur.

Shortgrass Steppe. We collected ramets from two populations of the cross-pollinated (Snyder and Harlan 1953), variably caespitose sod-forming grass, blue grama (Bouteloua gracilis [Willd. ex Kunt] Lag. ex Griffiths) in northeast Jalisco, Mexico (Table 1) in the southernmost extension of the shortgrass steppe (Aguado-Santacruz and Garcia-Moya 1998). Ramets were from adjacent sites (lat $21^{\circ} 46^{\prime} \mathrm{N}$, long $101^{\circ} 40^{\prime} \mathrm{W}, 2300 \mathrm{~m}$ a.s.l.) with contrasting grazing histories. One site (low grazing intensity) has had light to moderate grazing by cattle since about $1800\left(8 \mathrm{ha} \cdot \mathrm{AU}^{-1}\right.$; Arredondo et 
al. 2005). The other (high grazing intensity) is located on a site that has experienced unrestricted grazing by a variety of livestock species since about $1930\left(1.0-0.5 \mathrm{ha} \cdot \mathrm{AU}^{-1}\right)$. In January 2003 we excavated a total of 240 ramets from the two populations every $10 \mathrm{~m}$ along parallel $1200-\mathrm{m}$ north-south transects $400 \mathrm{~m}$ apart. Aboveground biomass and total vegetative cover has been shown to be significantly lower at this site than at the low-grazing-intensity site (AguadoSantacruz and García-Moya 1998).

Patagonian Steppe. In Argentina, we collected ramets of $\mathrm{Poa}$ ligularis Nees ex Steud., which is a dioecious (cross pollinated) caespitose grass species of the Patagonian steppe (Rotundo and Aguiar 2008). Populations characterized by a history of low or high grazing intensity were collected from sites at the Experimental Field Station INTA in Río Mayo, Chubut, Argentina (lat $45^{\circ} 41^{\prime} \mathrm{S}$, long $70^{\circ} 16^{\prime} \mathrm{W}, 500 \mathrm{~m}$ a.s.l.; Table 1 ). The sites differ in that the low-grazing-intensity site has experienced sheep (Ovis aries L.) exclusion since 1971. Prior to that time both sites were exposed to sheep grazing at a stocking rate of $12-25 \mathrm{ha} \cdot \mathrm{AU}^{-1}$ and stocking rates remained at this level at the high-grazing-intensity site.

We sampled ramets with the use of a strategy that attempted to capture both characteristics of the vegetation mosaic (Aguiar and Sala 1997) and wind dispersal, which is common at this site. In January 2003 we randomly placed five $10 \times 10 \mathrm{~m}$ grids along single transects within each site. Contiguous grids were separated by $30 \mathrm{~m}$. Inside each grid we randomly established $101-\mathrm{m}^{2}$ plots. In each plot, we collected two adjacent ramets located at least $0.2 \mathrm{~m}$ apart for a total of 200 ramets.

\section{Data Collection}

Ramets were transplanted into pots and maintained in greenhouses until tissue was collected for DNA extraction. DNA was extracted from ground leaf tissue following the protocol of Cluster et al. (1996) with the use of the DNeasy Plant Mini Kit (QIAGEN, Valencia, CA). For AFLP analysis we used a procedure described by Vos et al. (1995). This included 1) restriction digestion of 500-ng genomic DNA and ligation of adapters to create primary templates, 2) preamplification with AFLP primers with an additional single nucleotide at the $3^{\prime}$ end, 3) selective amplification with primers both having three selective nucleotides at the $3^{\prime}$ end, and 4) separation of products on a $6 \%$ denaturing polyacrylamide gel for 2.5 $3.5 \mathrm{~h}$ (depending on species) at $2000 \mathrm{~V}$.

\section{Data Analysis}

Gels were scanned with a double-bed scanner and Crosschecker v.1.0 was used to generate a binary matrix of data (including only bands $>150$ base pairs) that identified putative genets. Ramets where bands could not be clearly resolved are considered nongenotyped. We used random resampling $(N=999)$ and a permutation test to determine whether nongenotyped ramets occurred randomly within populations or the sampled areas. The proportion of distinguishable multilocus (multiband) genotypes was calculated following Ellstrand and Roose (1987; Table 2). Nei's intrapopulation gene diversity estimates averaged over markers were calculated with the use of AFLPdat software (Ehrich 2006) for all ramets 
excluding any duplicated genotypes. Confidence intervals for these estimates were generated by 999 bootstraps over markers. Also calculated was Simpson's (genotypic) diversity index as modified by Pielou (1969), which estimates the probability that two randomly selected ramets represent different genotypes. These diversity indices measure the frequencies of specific markers or marker genotypes independently within each population. Analysis of molecular variance (AMOVA) permits a combined assessment of the frequencies of specific markers over individuals between and within populations and therefore estimation of genetic differentiation between populations. This was accomplished with GENALEX 6 software (Peakall and Smouse 2006), which uses a pairwise Euclidean genetic distance matrix in calculations with binary data. Statistical significance of estimates of the fraction of genetic variation that occurs among populations $\left(\Phi_{p t}\right)$ was determined with the use of 999 random permutations.

We examined spatial genetic structure within populations with multilocus spatial genetic autocorrelation analysis in GENALEX 6. With the use of genetic and geographical distance matrices, GENALEX 6 calculates a genetic correlation coefficient $(r)$ across spatial distance classes. A random permutation calculation was executed $(N=999)$ to generate a $95 \%$ confidence interval (CI) for all distance class intervals. A $95 \%$ CI was also generated for each individual distance class interval based on 999 bootstraps. Under a conservative approach (Peakall and Smouse 2006), significant genetic spatial structuring was considered to occur when $|r|$ exceeded the permutation CI and when the bootstrap CI did not include $r=0$. We present autocorrelograms (Fig. 1) with distance classes that reflect the geographical extent of detectable spatial genetic structure in populations of each species derived from the Multiple Dclass option in GENALEX 6. Statistical significance was assigned at $P \leq 0.05$ throughout.

\section{RESULTS AND DISCUSSION}

\section{Descriptive Statistics: Genetic Diversity and Differentiation}

Clearly resolved bands were observed from 126 (48\%) of the ramets of sideoats grama, $171(71 \%)$ of blue grama ramets, and $198(99 \%)$ of $P$. ligularis ramets. There was no spatial or population-based pattern to the occurrence of nongenotyped ramets (data not shown). We also observed no apparent difference in the percent polymorphism between populations of any of the three species (Table 2). Multiple ramets with the same genotype were observed in both populations of sideoats grama and $P$. ligularis, whereas in blue grama, each ramet was a distinct genotype (Table 2).

Nei's gene diversity did not differ significantly (based on CI overlap) between populations when calculated on a ramet or individual genotype (genet) basis (Table 2). This indicates that the mean marker frequency over all markers-a proxy for allele frequency-was similar in each pair of populations. Likewise, Simpson's diversity index differed by less than $1 \%$ between the two populations where multiple ramets of a given genotype occurred (sideoats grama and P. ligularis). Overall, descriptive genetic statistics corroborated the majority of previous research suggesting that livestock grazing history is 

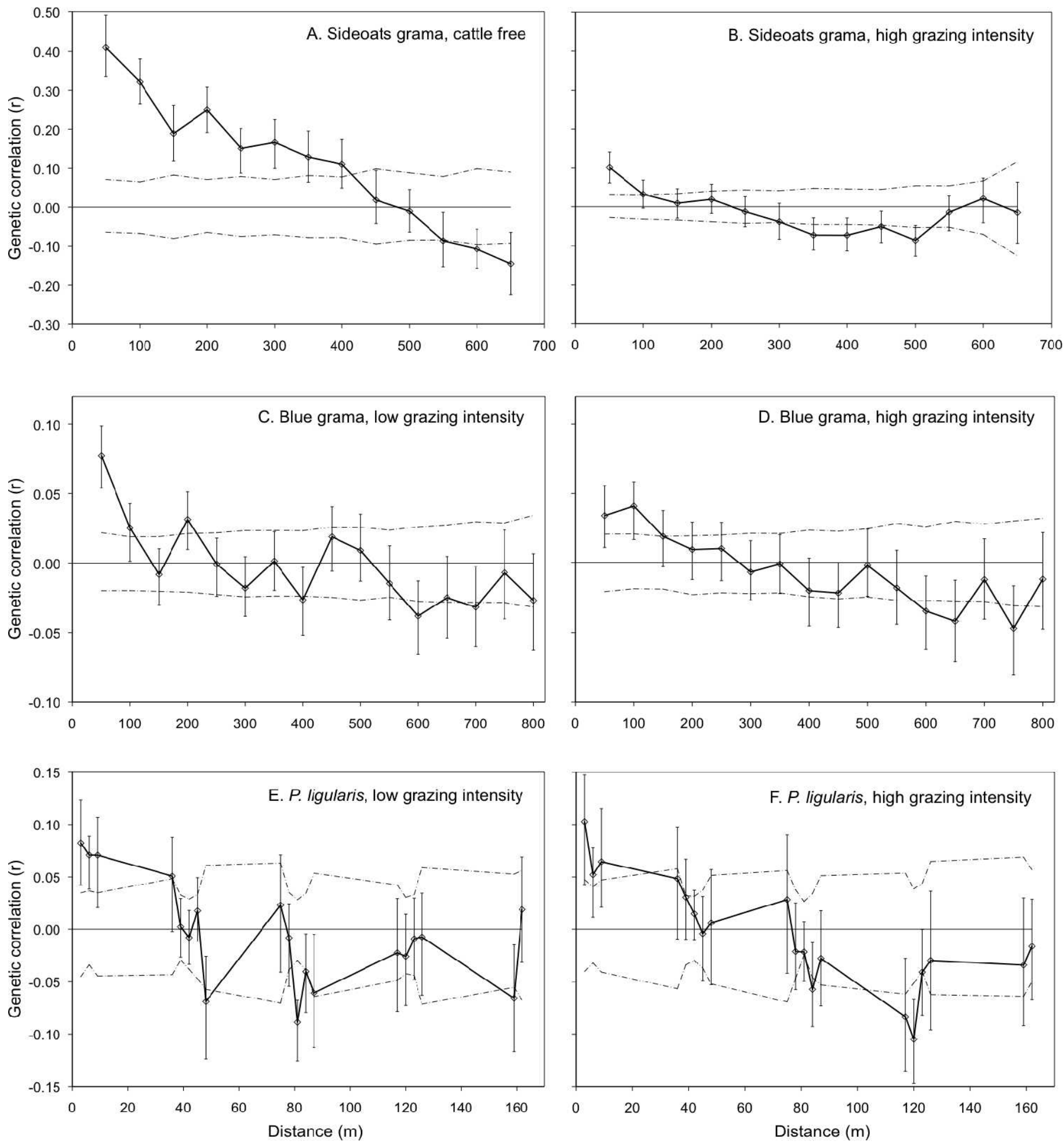

Figure 1. Correlograms showing the relationships between genetic correlation coefficient $(r)$ and distance in populations of sideoats grama not exposed to cattle (A) or with long-term exposure to cattle (B), blue grama exposed to low (C) or high (D) livestock grazing intensity, and Poa ligularis exposed to low (E) or high (F) livestock grazing intensity. Dashed lines represent 95\% confidence intervals based on 999 random permutations. Error bars represent $95 \%$ confidence intervals based on 999 bootstraps.

not associated with changes in intrapopulation genetic diversity in dominant grass species (Carman and Briske 1985; Tómas et al. 2000; Liston et al. 2003; Matlaga and Karoly 2004).
Although less than $2 \%$ of genetic variation occurred between the two populations in all species, AMOVA detected evidence of relatively slight but significant genetic differentiation associated with livestock grazing history between the popula- 
tions of sideoats grama $\left(\Phi_{p t}=1.53 \%\right)$ and $P$. ligularis $\left(\Phi_{p t}=1.02 \%\right)$ although not in blue grama $\left(\Phi_{p t}=0.27 \%\right)$. Similar grazing-associated differentiation in the absence of differences in genetic diversity has been observed before (Liston et al. 2003; Aguado-Santacruz et al. 2004).

\section{Spatial Genetic Structure}

Our results demonstrate that spatial genetic structure exists within each population of the three species (Fig. 1). Positive genetic structure exists when pairs of ramets within a distance class are more closely related than would be expected with random selection, and was present in all populations within at least the smallest distance class. We also noted an indication of differences in the form of the genetic structure between populations in two of the species. The magnitude of the positive genetic correlation coefficient was relatively high (maximum $r=0.41, \mathrm{CI}=0.34-0.49$ ) and extended furthest $(400 \mathrm{~m})$ in the cattle-free population of sideoats grama (Fig. 1A). The maximum correlation coefficient $(r=0.08$ at $0-50 \mathrm{~m}, \mathrm{CI}=0.06-0.10$ ) was also comparatively high in the low-grazing-intensity population of blue grama. Significant positive genetic correlation was present within both populations of $P$. ligularis but only in the distance classes within an individual $10 \times 10 \mathrm{~m}$ grid $(0-9 \mathrm{~m}$; Figs. $1 \mathrm{E}$ and $1 \mathrm{~F})$.

Significant negative spatial genetic structure also occurred in all populations. This occurs when pairs of ramets within this distance are less closely related than would be expected with random selection. Negative genetic structure was observed in distance classes that extended beyond $300 \mathrm{~m}$ in sideoats grama, $350 \mathrm{~m}$ in blue grama, and $45 \mathrm{~m}$ in P. ligularis. Again, the most marked evidence of a possible difference between populations was in sideoats grama, where significant negative genetic correlation occurred first at greater distances in the cattle-free population $(550 \mathrm{~m})$ than in the grazed population $(350 \mathrm{~m}$; Figs. $1 \mathrm{~A}$ and $1 \mathrm{~B}$ ). A significant difference in genetic correlation between populations was also observed beyond $100 \mathrm{~m}$ in $P$. ligularis (Figs. 1E and $1 \mathrm{~F}$ ).

Dissimilarities in spatial genetic structure between populations with different grazing histories could suggest that the presence of livestock may affect this population attribute. We hypothesize that the activities of grazing livestock may result in reductions in the size of genetic neighborhood areas (the area surrounding an individual plant within which there is a high probability of finding its parents) and result in spatial genetic homogenization within areas where animals actively graze. In sideoats grama, the presence of a large area with positive genetic structure in the absence of livestock (Figs. 1A and 1B) does suggest an increase in the size of genetic neighborhood areas. Apparent differences in the size of these areas between populations were observed even though the distance between adjacent sampled ramets was smaller on average in the grazed population than in the cattle-free population $(6 \mathrm{~m}$ vs. $11 \mathrm{~m})$. Reduced sampling distance in the grazed site should actually increase the probability of observing patches of closely related ramets if they were present.

Patterns of spatial genetic structure are the result of complex interactions among plant mating system, dispersal, and demography, and the behavior of dispersal and defoliating agents. Livestock could alter spatial genetic structure through several processes, including dispersal of seeds and vegetative propagules (Willerding and Poschlod 2002), and defoliation patterns, which could affect establishment via seeds (Butler and Briske 1988; Coffin and Lauenroth 1992; Frank 2005), or influence inbreeding (Falkner and Casler 2000). Livestock may also alter opportunities for seedling establishment by changing safe site characteristics (Coffin and Lauenroth 1992; Frank 2005).

It is important to stress that any differences we noted in spatial genetic structure between populations could be unrelated to grazing history. For example, they may reflect differences in edaphic or biological features between the sites. Further research would be needed to confirm that differences in genetic structure we suggest could be related to livestock grazing. Executing such research generally presents many challenges. For example, in rangeland communities where livestock were once present, altered genetic conditions may persist after even decades of livestock exclusion (Trlica and Orodho 1989). Genetic effects associated with grazing treatments may also be concealed by the effects of gene flow between areas differing in grazing history (Matlaga and Karoly 2004). Both of these confounding factors may have existed in our research as well as in much of the previous work on grazing history effects on genetic structure.

Future experiments could involve random imposition of treatments with different livestock grazing intensities within an environment where livestock had never been present. These treatments could be imposed within an artificial community where all propagules of plant species of interest are introduced by the experimenters. This approach may also offer the advantages of standardized edaphic conditions, plant age, initial genetic diversity, and spatial relationships across grazing treatments although intertreatment gene flow could still be a problem. A significant potential disadvantage of these approaches is that long periods of time may be required for any livestock-associated changes in genetic variation to be recognizable. Translating conclusions from artificial communities to native rangelands is also likely to be complicated, although this experimental approach otherwise appears to offer the highest probability of success. Attempts to understand any changes in genetic structure associated with grazing would ideally be coupled with careful examination of plant demography, especially all modes of dispersal.

\section{IMPLICATIONS}

We have demonstrated the existence of nonrandom spatial genetic structure within populations of three perennial grasses in rangeland environments. Our data for sideoats grama also suggest that livestock grazing could result in alterations in finescale genetic structure compared to the situation where livestock are absent. We suggest that a natural extension of our findings would be to investigate further how grazing animals might affect spatial genetic structure. Experimental approaches based on artificial communities would appear to offer the best opportunities for developing a more comprehensive understanding of grazing effects on plant evolutionary potential. 


\section{ACKNOWLEDGMENT}

We thank Veronica Zarate for her technical assistance.

\section{LITERATURE CITED}

Aarssen, L. W., and R. Turkington. 1987. Responses to defoliation in Holcus lanatus, Lolium perenne, and Trifolium repens from three different-aged pastures. Canadian Journal of Botany 65:1364-1370.

Aguado-Santacruz, G. A., and E. Garcia-Moya. 1998. Environmental factors and community dynamics at the southernmost part of the North American Graminetum. I. On the contribution of climatic factors to temporal variation in species composition. Plant Ecology 135:13-29.

Aguado-Santacruz, G. A., N. E. Leyva-Lopez, K. I. Perez-Marquez, E. Garcia-Moya, J. T. Arredondo-Moreno, and J. P. Martinez-Soriano. 2004. Genetic variability of Bouteloua populations differing in forage production at the southernmost part of the North American Graminetum. Plant Ecology 170:287-299.

Aguiar, M. R., And O. E. Sala. 1997. Seed distribution constrains the dynamics of the Patagonian steppe. Ecology 78:93-100.

Arredondo, J. T., E. Huber-Sannwald, E. García Moya, M. Gárcia Holguín, and G. A. Aguado-Santacruz. 2005. Selección de germoplama de zacate navajita con diferente historical de uso en Jalisco, Mexico. Tecnica Pecuaria 43: 371-385.

Asner, G. P., A. J. Elmore, L. P. Olander, R. R. Martin, and A. T. Harris. 2004. Grazing systems, ecosystem responses, and global change. Annual Review of Environment and Resources 29:261-299.

Briske, D. D., and V. J. Anderson. 1992. Competitive ability of the bunchgrass Schizachyrium scoparium as affected by grazing history and defoliation. Vegetatio 193:41-49.

Briske, D. D., and J. H. Richards. 1995. Plant responses to defoliation: a physiologic, morphologic and demographic evaluation. In: D. J. Bedunah and S. E. Sosebee [EDS.]. Wildland plants: physiological ecology and developmental morphology. Denver, CO, USA: Society for Range Management. p. $635-710$.

Brown, D. E. 1994. Semidesert grasslands. In: D. E. Brown [ed.]. Biotic communities: southwestern United States and northwestern Mexico. Salt Lake City, UT, USA: University of Utah Press. p. 123-135.

ButLeR, J. L., AND D. D. BrISKE. 1988. Population structure and tiller demography of the bunchgrass Schizachyrium scoparium in response to herbivory. Oikos 51:306-312.

Carman, J. G., and D. D. Briske. 1985. Morphological and allozymic variation between long-term grazed and non-grazed populations of the bunchgrass Schizachyrium scoparium var. frequens. Oecologia 66:332-337.

Cluster, P. D., M. O'Dell, M. Metzlaff, and R. B. Flavell. 1996. Details of T-DNA structural organization from a transgenic Petunia population exhibiting $\mathrm{CO}^{-}$ suppression. Plant Molecular Biology 32:1197-1203.

Coffin, D. P., And W. K. Lauenroth. 1992. Spatial variability in seed production of the perennial bunchgrass Bouteloua gracilis (Gramineae). American Journal of Botany 79:347-353.

Crutsinger, G. M., M. D. Collins, J. A. Fordyce, Z. Gompert, C. C. Nice, and N. J. Sanders. 2006. Plant genotypic diversity predicts community structure and governs an ecosystem process. Science 313:966-968.

Díaz, S., I. Noy-Meir, and M. CaBido. 2001. Can grazing response of herbaceous plants be predicted from simple vegetative traits? Journal of Applied Ecology 38:497-508.

EHRICH, D. 2006. AFLPDAT: A collection of $R$ functions for convenient handling of AFLP data. Molecular Ecology Notes 6:603-604.

Ellstrand, N. C., and M. L. Roose. 1987. Patterns of genotypic diversity in clonal plant species. American Journal of Botany 74:123-131.

FalkneR, L. K., AND M. D. CASLeR. 2000. Genetic shifts in smooth bromegrass under grazing: changes in nutritional value and preference for surviving vs. original genotypes. Grass and Forage Science 55:351-360.
Folke, C. S., S. R. Carpenter, B. H. Walker, M. Scheffer, T. Elmovist, L. H. Gunderson, AND C. S. HolıIng. 2004. Regime shifts, resilience, and biodiversity in ecosystem management. Annual Review Ecology, Evolution and Systematics 35:557-581

Frank, D. A. 2005. The interactive effects of grazing ungulates and aboveground production on grassland diversity. Oecologia 143:629-634.

Fu, Y. B., D. Thompson, W. Willms, And M. Mackay. 2005. Long-term grazing effects on genetic variability in mountain rough fescue. Rangeland Ecology and Management 58:637-642.

Gould, F. W. 1951. Notes on apomixis in sideoats grama. Journal of Range Management 12:25-28.

Hadley, D., P. Warshall, and D. Bufkin. 1991. Environmental change in Aravaipa, 1870-1970: an ethnoecological survey. Cultural Resource Series 7. Phoenix, AZ, USA: Arizona Bureau of Land Management. 368 p.

Harlan, J. R. 1949. Apomixis in side-oats grama. American Journal of Botany 36:495-499.

HeYwood, J. S. 1991. Spatial analysis of genetic variation in plant populations. Annual Review Ecology and Systematics 22:335-355.

Liston, A., B. L. Wilson, W. A. Robinson, P. S. Doescher, N. R. Harris, and T. Svejcar. 2003. The relative importance of sexual reproduction versus clonal spread in an arid bunchgrass. Oecologia 137:216-225.

Matlaga, D., and K. Karoly. 2004. Assessing the consequences of long-term cattle grazing on genetic variation in Idaho fescue (Poaceae) using ISSR markers. Journal of Range Management 57:275-279.

Mengli, Z., W. D. Willms, H. Bing, and A. Laroche. 2005. Effects of heavy grazing pressure on the random amplified polymorphic DNA marker diversity of mountain rough fescue (Festuca campestris Rydb.) in southwestern Alberta. Canadian Journal of Plant Science 85:623-629.

Milchunas, D. G., and W. K. Lauenroth. 1993. Quantitative effects of grazing on vegetation and soils over a global range of environments. Ecological Monographs 63:327-366.

Milchunas, D. G., W. K. Lauenroth, and I. C. Burke. 1998. Livestock grazing: animal and plant biodiversity of shortgrass steppe and the relationship to ecosystem function. Oikos 83:65-74.

MıLCHunas, D. G., AND I. Noy-Meir. 2002. Grazing refuges, external avoidance of herbivory and plant diversity. Oikos 99:113-130.

Noy-MeIR, I., AND D. D. BrISKE. 2002. Response of wild wheat populations to grazing in Mediterranean grasslands: the relative influence of defoliation, competition, mulch and genotype. Journal of Applied Ecology 39:259-278.

Peakall, R., and P. E. Smouse. 2006. GenaleX 6. Genetic análisis in Excel. Population genetic software for teaching and research. Molecular Ecology Notes 6:288-295.

Pielou, E. C. 1969. An introduction to mathematical ecology. New York, NY, USA: Wiley. $286 p$.

Poley, H. W., and J. K. Detling. 1990. Grazing-mediated differentiation in Agropyron smithii: evidence from populations with different grazing histories. Oikos 57:326-332.

Rotundo, J. L., AND M. R. Aguiar. 2008. Herbivory resistance traits in populations of Poa ligularis subjected to historically different sheep grazing pressure in Patagonia. Plant Ecology 194:121-133.

Scheiner, S. M., And J. Gurevitch. 2001. Design and analysis of ecological experiments. 2nd ed. New York, NY, USA: Oxford University Press. $415 \mathrm{p}$.

SivakumaR, M. V. K., H. P. DAS, AND 0. BRUnIII. 2005. Impacts of present and future climate variability and change on agriculture and forestry in the arid and semiarid tropics. Climatic Change 70:31-72.

Sмıтн, S. E. 1998. Variation in response to defoliation between populations of Bouteloua curtipendula var. caespitosa (Poaceae) with different livestock grazing histories. American Journal of Botany 85:1266-1272.

Smith, S. E., R. Mosher, and D. Fendenheim. 2000. Seed production in sideoats grama populations with different grazing histories. Journal of Range Management 53:550-555.

Snyder, L. A., AND J. R. Harlan. 1953. A cytological study of Bouteloua gracilis from western Texas and eastern New Mexico. American Journal of Botany 40:702-707. 
Tómas, M. A., A. D. Carrera, and M. Poverene. 2000. Is there any genetic differentiation among populations of Piptochaetium napostaense (Speg.) Hack (Poaceae) with different grazing histories? Plant Ecology 147:227-235.

TrLica, M. J., AND A. B. ORodHo. 1989. Effects of protection from grazing on morphological and chemical characteristics of Indian ricegrass, Oryzopsis hymenoides. Oikos 56:299-308.
Vos, P., R. Hogers, M. Bleeker, M. Reijans, T. Van de Lee, M. Hornes, A. Freijters, J. Рot, J. Peleman, M. Kuiper, and M. Zabeau. 1995. AFLP: a new concept for DNA fingerprinting. Nucleic Acids Research 23:4407-4414.

Willerding, C., and P. Poschlod. 2002. Does seed dispersal by sheep affect the population genetic structure of the calcareous grassland species Bromus erectus. Biological Conservation 104:329-337. 